\title{
Special Session: Macromarketing Saving the World: An Abstract
}

\author{
Ben Wooliscroft, Sanna Ganglmair-Wooliscroft, Joya Kemper, \\ Mark Peterson, Ann-Marie Kennedy, and Andy Prothero
}

\begin{abstract}
This special session for the 2017 AMS World Marketing Congress focuses on the role of macromarketing in solving the world's social, environmental, and economic issues. George Fisk once said that "The purpose of macromarketing is to save the world" (Fisk 2001). This session discusses the purpose and areas of macromarketing, expanding the knowledge of those who might be unfamiliar with macromarketing but wish to contribute to the field. Panel members will provide an overview of macromarketing foundations and research areas, such as quality of life, sustainability, ethics, history, and macro-social marketing. Lastly, a discussion on publishing in the associations journal, the Journal of Macromarketing, will provide an overview to those wishing to establish scholarship in the field. Overall, this session will provide a general overview of macromarketing to the Academy of Marketing Science community.
\end{abstract}

B. Wooliscroft $\bullet$ S. Ganglmair-Wooliscroft University of Otago, Dunedin, New Zealand

e-mail: ben.wooliscroft@otago.ac.nz; alexandra.ganglmair@otago.ac.nz

J. Kemper $(\bowtie) \bullet$ A.-M. Kennedy

University of Canterbury, Christchurch, New Zealand

e-mail: joya.kemper@pg.canterbury.ac.nz; ann-marie.kennedy@ canterbury.ac.nz

M. Peterson

University of Wyoming, Laramie, WY, USA

e-mail: markpete@uwyo.edu
A. Prothero
University College Dublin, Dublin, Ireland
e-mail: andrea.prothero@ucd.ie 